bioRxiv preprint doi: https://doi.org/10.1101/2020.05.28.120972; this version posted May 28, 2020. The copyright holder for this preprint (which

was not certified by peer review) is the author/funder, who has granted bioRxiv a license to display the preprint in perpetuity. It is made available under aCC-BY 4.0 International license.

Oleszczuk et al.

Plant Disease

Page 1 of 1

\title{
1 Characterization of Components of Resistance to Corn Stunt Disease
}

2 José D. Oleszczuk, ${ }^{1}$ María I. Catalano, ${ }^{2}$ Lucía Dalaisón, ${ }^{2}$ Julio A. Di Rienzo, ${ }^{3}$ María P.

3 Giménez Pecci, ${ }^{4}$ and Pablo D. Carpane ${ }^{1,{ }^{*}}$

4 1: Bayer Argentina. Fontezuela, Buenos Aires, Argentina.

5 2: Centro de Investigaciones en Biología (CEBIO), Pergamino, Buenos Aires, Argentina.

6 3: Cátedra de Estadística y Biometría. Facultad de Ciencias Agropecuarias, Universidad

7 Nacional de Córdoba. Córdoba, Argentina.

8 4: Instituto Nacional de Tecnología Agropecuaria (INTA) Instituto de Patología Vegetal

9 (IPAVE). Córdoba, Argentina.

$10 *$ : corresponding author. P.D. Carpane. E-mail: pablo.carpane@bayer.com

Abstract

12
Considering the occasional but increasing presence of corn stunt disease in the subtropical region of Argentina, the objective of this research was to devise an effective strategy to screen disease-resistant genotypes in the absence of high and constant natural pressures.

To do so, the presence of antixenosis and antibiosis as components of resistance to vector Dalbulus maidis (DeLong 1923) as well as resistance to the pathogen Spiroplasma kunkelii (Whitcomb et al. 1986) under artificial inoculation conditions were investigated in four widely-distributed maize hybrids in Argentina. The hybrids shown differences in the levels of resistance and target organisms (either the insect vector or the pathogen). Antixenosis 
bioRxiv preprint doi: https://doi.org/10.1101/2020.05.28.120972; this version posted May 28, 2020. The copyright holder for this preprint (which

was not certified by peer review) is the author/funder, who has granted bioRxiv a license to display the preprint in perpetuity. It is made available under aCC-BY 4.0 International license.

Oleszczuk et al.

Plant Disease

Page 2 of 1

20

21

22

23

24

25

26

27

28

29

30

31

32

33

34

35

36

37

38

39

40

and antibiosis to D. maidis were observed in DK72-10. Resistance of DK79-10 to S. kunkelii

was evidenced by a delayed onset of symptoms, and DKB390 was antixenotic to $D$. maidis

and highly resistant to S. kunkelii. A good association was found between symptom

severity and yield, but not between symptom severity and accumulation of pathogen $S$.

kunkelii. In conclusion, the proposed methodology was efficacious and can aid the

screening of resistant genotypes in breeding programs to reduce the impact of corn stunt

disease, ensuring that hybrids with good resistance level will be planted by farmers

whenever disease occurs.

Corn stunt, Spiroplasma kunkelii, Dalbulus maidis, Disease resistance

Keywords

Introduction

Corn stunt is one of the most significant diseases affecting maize crop in the Americas, because of its high prevalence and its potential to cause yield losses in endemic areas (Bajet and Renfro 1989; Bradfute et al. 1981; Oliveira et al. 1998). Following its initial detection (Alstatt 1945; Frazier 1945), its prevalence has increased in the Americas (Bradfute et al. 1981; Hruska et al. 1996; Giménez Pecci et al. 2002; 2005). Corn stunt disease was first confirmed in the subtropical region of Argentina during the 1990/91 crop season (Lenardón et al. 1993). High disease prevalence was later reported in this region in certain crop seasons (Giménez Pecci et al. 2002; Virla et al. 2003), and isolated symptomatic plants may be found occasionally in temperate areas of Argentina (Carloni 2010; Carloni et al. 2013; Giménez Pecci et al. 2002; 2003; 2005). 
bioRxiv preprint doi: https://doi.org/10.1101/2020.05.28.120972; this version posted May 28, 2020. The copyright holder for this preprint (which

was not certified by peer review) is the author/funder, who has granted bioRxiv a license to display the preprint in perpetuity. It is made available under aCC-BY 4.0 International license.

Oleszczuk et al.

Plant Disease

Page 3 of 1

41 The mollicute Spiroplasma kunkelii (Whitcomb et al. 1986), known as Corn Stunt

42 Spiroplasma (CSS), is the pathogen most commonly associated with corn stunt disease in

43 Argentina. This mollicute is transmitted by leafhoppers, being Dalbulus maidis (DeLong

44 1923) the only vector species identified in field-collected samples in Argentina (Giménez

45 Pecci et al. 2003; Virla et al. 1990; Paradell et al. 2001), although Exitianus obscurinervis

46 (Stal 1859) (Hemiptera: Cicadellidae) was proven to be a vector species in experimental

47 conditions (Carloni et al. 2011). The epidemiological significance of $D$. maidis lies in its high

48 prevalence (Nault 1990), high transmission efficiency of the pathogen S. kunkelii, with no

49 reduced longevity (Alivizatos and Markham 1986; Nault 1990), and the persistent-

50 propagative transmission mode of the pathogen, so insects acquiring the pathogen remain

51 inoculative throughout their lifespan (Nault 1980).

52 Symptoms of corn stunt disease appear three to five weeks after inoculation and typically

53 include chlorotic stripes that appear near the leaf base (Nault 1980), extending further

54 towards the leaf tips (Kunkel 1946) and may cover the entire leaf, as well as younger

55 leaves. In other cases, leaves may exhibit reddening (Oliveira et al. 1998) or deformations

56 ("cuts") in the margins. Plants may have shortened internodes, which gives its name to

57 stunting, and in some cases ear proliferation (Nault 1980). Symptoms are usually more

58 severe towards the upper part of the plant and may impair the development of

59 reproductive structures of the plants (Carpane et al. 2006; Nault 1980). Reduced yield

60 resulting from corn stunt disease is directly related to symptom severity and the

61 accumulation of the pathogen S. kunkelii (Virla et al. 2004), which are both highest if S.

62 kunkelii is inoculated at early growth stages (Massola Junior et al. 1999b; Scott et al. 
bioRxiv preprint doi: https://doi.org/10.1101/2020.05.28.120972; this version posted May 28, 2020. The copyright holder for this preprint (which

was not certified by peer review) is the author/funder, who has granted bioRxiv a license to display the preprint in perpetuity. It is made available under aCC-BY 4.0 International license.

Oleszczuk et al.

Plant Disease

Page 4 of 1

63 1977). In this situation, reduced yield may be high, ranging from 12 to $100 \%$ (Hruska and

64 Gomez Peralta 1997; Massola Junior et al. 1999b; Oliveira et al. 2003; Scott et al. 1977).

65 One of the most convenient alternatives to reduce yield loss resulting from diseases is the use of resistant crops (Hogenboom 1993). The resistance of maize genotypes to S. kunkelii

67 might remain stable over time and across regions due to the low genomic variation of this

68

69

70

71

72

73

74

75

76

77

78

79

80

81

82 83 pathogen (Carpane et al. 2013). Field-resistant genotypes have in fact been obtained in areas of high pressure (Castañón et al. 2003; Gómez 2012; Hidalgo et al. 1998; Mendoza et al. 2002; Rodriguez and Preciado 1988; Scott and Rosenkranz 1977). However, the rare incidence of corn stunt disease in Argentina hinders the effective identification of resistant genotypes to this disease. The accurate detection of resistant genotypes may play a key role in the management of corn stunt disease in areas where the planting of temperate genotypes (obtained in areas where the prevalence of corn stunt is low or null) has increased over the past years ahead of tropical genotypes, which should a priori be more resistant to corn stunt for being obtained in a disease endemic area.

In the absence of high and constant natural pressures, the analysis of resistance mechanisms to corn stunt may be effective to select resistant genotypes (Azzam and Chancellor 2002; Carpane 2007), with the possibility to identify and combine several resistance mechanisms. For instance, the resistance of most genotypes is targeted to vector insects via antixenosis or antibiosis in other pathosystems (Rezaul Karim and Saxena 1991; Saxena 1987), thereby reducing the effectiveness of pathogen inoculation.

In other cases, resistance seems to be aimed to the pathogen, since maize genotypes 
bioRxiv preprint doi: https://doi.org/10.1101/2020.05.28.120972; this version posted May 28, 2020. The copyright holder for this preprint (which

was not certified by peer review) is the author/funder, who has granted bioRxiv a license to display the preprint in perpetuity. It is made available under aCC-BY 4.0 International license.

Oleszczuk et al.

Plant Disease

Page 5 of 1

84 resistant to corn stunt show milder symptoms and a smaller yield reduction (Caro et al.

85 2008; 2009; Hidalgo et al. 1998).

86 The goal of this research was to identify the presence and to characterize resistance

87 mechanisms to corn stunt disease in maize hybrids from temperate and tropical regions of

88 Argentina, which would later allow to generate a screening methodology to be used in the

89 absence of high corn stunt pressures.

\section{Materials and Methods}

91 The tests implemented investigated the existence of different resistance mechanisms to

92 corn stunt disease: antixenosis and antibiosis to vector D. maidis (Saxena 1987) and

93 resistance to pathogen S. kunkelii (Hogenboom 1993).

$94 \quad$ Biological Materials

95 A colony of healthy D. maidis was initiated from insects collected in the province of

96 Tucumán (located in the tropical area of Argentina) and was maintained on plants of

97 sweet corn variety Maizón at the IPAVE-CIAP (Plant Pathology Research Institute - Center

98 of Agricultural Research (IPAVE-CIAP) at INTA (National Institute of Agricultural

99 Technology) Córdoba, Argentina and at CEBIO (BioResearch Center) at UNNOBA-CICBA

100 (National University of the North West of the Province of Buenos Aires - Scientific

101 Research Commission of the Province of Buenos Aires), Pergamino, Buenos Aires,

102 Argentina. The colonies were kept in aluminum-framed cages with a "voile" type nylon 
bioRxiv preprint doi: https://doi.org/10.1101/2020.05.28.120972; this version posted May 28, 2020. The copyright holder for this preprint (which

was not certified by peer review) is the author/funder, who has granted bioRxiv a license to display the preprint in perpetuity. It is made available under aCC-BY 4.0 International license.

Oleszczuk et al.

Plant Disease

Page 6 of 1

103 mesh, placed in a growth chamber at a temperature of $25^{\circ} \mathrm{C}$, with a photoperiod of $16: 8$

104 (light: darkness) hours (Nault 1980).

105 Maize hybrids DK670 and DK72-10 which were selected in the temperate region of 106 Argentina, and DK79-10 and DKB390 which were obtained from the tropical region of 107 Argentina. The seed was obtained directly from Bayer's seed processing facilities before 108 they were treated, and for this reason they had no insecticides nor fungicides.

Preference Test (Antixenosis to the vector Dalbulus maidis)

111 The test was performed under controlled conditions at CEBIO at a mean temperature of

$112 \quad 20-30^{\circ} \mathrm{C}$ using seeds planted in pots (1 seed per pot).

113 Plants with two fully expanded leaves were used. A plant from each hybrid was

114 transferred into a glass cage. Pots were placed horizontally on the cage floor, so plants

115 could be mounted in such a way that they exposed only a single leaf with its abaxial side

116 upwards. Six two-week-old adult D. maidis mated females were later introduced into the

117 cage.

118 Preference was determined by recording the number of insects settled on each hybrid or

119 not settled on any hybrid at 1, 6, 24 and 48 hours (timepoints) after their release. At the 120 end of the test, leaves were dissected using a binocular microscope to count the number 121 of eggs. 
bioRxiv preprint doi: https://doi.org/10.1101/2020.05.28.120972; this version posted May 28, 2020. The copyright holder for this preprint (which

was not certified by peer review) is the author/funder, who has granted bioRxiv a license to display the preprint in perpetuity. It is made available under aCC-BY 4.0 International license.

Oleszczuk et al.

Plant Disease

Page 7 of 1

123 The experiment was replicated 50 times, with each cage of four hybrids and six females

124 serving as a replication. The arrangement of hybrids was randomized across replications.

125 For the statistical analysis, a multinomial model was adjusted modeling hybrid and

126 timepoints effects. The model was adjusted using the nnet package (Venables and Ripley

127 2002) of $R$ language ( $R$ Core Team 2018). The response variable was the proportion of

128 insects settled on each hybrid or on the cage. The significance of the differences in

129 intercepts and slopes in the interaction was analyzed with contrasts using this same

130 module. A generalized linear mixed model was used for oviposition to model negative

131 binomial variables, with hybrid as fixed effect and replication as random effect.

\section{Survival Test (Antibiosis to the vector Dalbulus maidis)}

$\underline{\text { Test Conditions }}$

134 The test was performed under controlled conditions in IPAVE-CIAP at a temperature of

$135 \quad 20-30^{\circ} \mathrm{C}$ using seeds planted in pots (1 seed per pot).

136 The test was conducted in plants with two fully expanded leaves. Each replication

137 consisted of four polyethylene cages each containing a plant from one of the hybrids. Five

138 two-week-old adult D. maidis mated females were then released. The number of surviving

139 insects was counted weekly for four weeks (timepoints), and plants were replaced to

140 ensure the presence of fresh plants. 
bioRxiv preprint doi: https://doi.org/10.1101/2020.05.28.120972; this version posted May 28, 2020. The copyright holder for this preprint (which

was not certified by peer review) is the author/funder, who has granted bioRxiv a license to display the preprint in perpetuity. It is made available under aCC-BY 4.0 International license.

Oleszczuk et al.

Plant Disease

Page 8 of 1

142 The experiment was replicated 30 times, being a replication each group of four

143 polyethylene cages containing each cage one hybrid and five insects. The distribution of 144 cages was randomized across replication. For the statistical analysis, a generalized linear 145 mixed model was used, being hybrid, timepoint and interaction fixed effects. The 146 response variable was the probability of survival, with binomial distribution and a logit 147 linkage function.

149 To prevent reduced inoculation efficiency of pathogen S. kunkelii due to the potential 150 presence of antixenosis and antibiosis to vector $D$. maidis by the hybrids tested, the 151 artificial infestation took place using a high pressure of inoculative insects in no-choice 152 conditions (Alivizatos and Markham 1986; Azzam and Chancellor 2002). This was

153 considered enough to ensure that $S$. kunkelii was indeed inoculated to all plants as in 154 other pathosystems (Shibata et al. 2007). Test Conditions

156 A population of inoculative $D$. maidis was initiated by collecting symptomatic plants in Las 157 Breñas, Province of Chaco, which were taken to IPAVE-CIAP. The acquisition of S. kunkelii 158 from these plants and its subsequent maintenance was conducted according to Nault 159 (1980) and adapted by Carpane (2007), in terms of acquisition access (7 days), incubation 160 (21 days) and inoculation access (7 days) periods. Before the test, inoculative D. maidis 
bioRxiv preprint doi: https://doi.org/10.1101/2020.05.28.120972; this version posted May 28, 2020. The copyright holder for this preprint (which

was not certified by peer review) is the author/funder, who has granted bioRxiv a license to display the preprint in perpetuity. It is made available under aCC-BY 4.0 International license.

Oleszczuk et al.

Plant Disease

Page 9 of 1

161 were placed in glass test tubes (height: $15 \mathrm{~cm}$; diameter: $2 \mathrm{~cm}$ ) in groups of six adult

162 insects and were transferred into the field where inoculation took place. Insects were not

163 sexed, because transmission efficiency is similar in both genders (Alivizatos and Markham

164 1986).

165 Inoculation was performed in a field close to Monte Cristo, Province of Córdoba, at $30 \mathrm{~km}$

166 from IPAVE-CIAP. The presence of corn stunt disease in this area is typically low or null,

167 thus minimizing the risk of natural infections from $D$. maidis interfering with forced

168 inoculation. Plots of nine 500-meter-long rows were planted of each hybrid, with a row

169 spacing of $52 \mathrm{~cm}$ and a density of 3.5 seeds per linear meter. At the four-leaf stage, five

170 homogeneous blocks were labeled, and five plants of similar size were selected in each of

171 them and individually covered with a "voile" type nylon cage. Insects were released into

172 each cage (a tube containing six insects per plant) for an inoculation access period (IAP) of

17348 hours, long enough to obtain maximum inoculation efficiency of S. kunkelii (Alivizatos

174 and Markham 1986). As negative control, five plants of each hybrid were exposed to

175 insects from the healthy colony (six adults per plant). Following the IAP, insects were

176 controlled with insecticides and cages were removed. Insecticides were periodically

177 sprayed later to prevent natural inoculation of $S$. kunkelii by eventual populations of $D$.

178 maidis or by insects hatching from eggs laid in inoculated plants.

$179 \quad$ Progression of Disease Incidence and Severity

180 Symptom severity was assessed at 20, 45, 65 and 85 days after inoculation (DAI)

181 timepoints. A 0-4 grade scale (based on Carpane et al. 2006) was used for the assessment, 
bioRxiv preprint doi: https://doi.org/10.1101/2020.05.28.120972; this version posted May 28, 2020. The copyright holder for this preprint (which

was not certified by peer review) is the author/funder, who has granted bioRxiv a license to display the preprint in perpetuity. It is made available under aCC-BY 4.0 International license.

Oleszczuk et al.

Plant Disease

Page 10 of 1

182 where $0=$ no symptoms, 1 = leaves with red margins (red leaves), 2 = leaves with chlorotic

183 stripes, 3 = leaves with mild stunting (height $15-30 \%$ of non-inoculated plants), $4=$ leaves

184 with severe stunting, with a height lower than $30 \%$ of non-inoculated plants.

Detection of the Pathogen S. kunkelii

186

In the last timepoint of symptom assessment (85 DAI), tissue samples from the ear leaf

187 and the penultimate leaf from the tassel were collected to diagnose the presence of $S$.

188 kunkelii at IPAVE-CIAP. A sample of $0.5 \mathrm{~g}$ leaf was cut and macerated in $5 \mathrm{~mL}$ of PBST

189 (Shibata et al. 2007). The accumulation of S. kunkelii was estimated using a double

190 antibody sandwich enzyme-linked immunosorbent assay (DAS-ELISA) conjugated with

191 alkaline phosphatase (Giménez Pecci et al. 2009). S. kunkelii accumulation was expressed

192 as relative absorbance (RA), this being the ratio between absolute absorbance at $405 \mathrm{~nm}$

193 of each leaf sample and a threshold of absorbance (mean +3 standard deviations of

194 absolute absorbance) obtained from six healthy plants of each hybrid (Sutula et al. 1986).

195 Plants were considered positive (with presence of the pathogen S. kunkelii) if RA was

196 higher to 1 in any of the leaves tested.

198 When grain moisture of DK72-10 (intermediate relative maturity of the hybrids tested)

199 reached 16\%, ears from each plant were harvested individually to determine yield

200 (g/plant), which was expressed as qq/Ha, with an estimated planting density of 70,000

201 plants/Ha and a grain moisture of $14.5 \%$. In turn, to neutralize the effect of yield potential 
bioRxiv preprint doi: https://doi.org/10.1101/2020.05.28.120972; this version posted May 28, 2020. The copyright holder for this preprint (which

was not certified by peer review) is the author/funder, who has granted bioRxiv a license to display the preprint in perpetuity. It is made available under aCC-BY 4.0 International license.

Oleszczuk et al.

Plant Disease

Page 11 of 1

203

204

each plant and the average yield of ten non-inoculated plants from the same hybrid (all these plants were diagnosed negative for S. kunkelii) and expressed as percentage.

\section{Experimental Design and Statistical Analysis}

The statistical analysis of symptom progression was performed using a generalized mixed linear model with hybrid, timepoints (DAIs) and interaction as fixed effects. The response variables were binary (logit linkage): the incidence of plants with symptoms and plants with severe symptoms (grades of 3 or 4 in the scale mentioned above). The number of plants with a positive diagnose in DAS-ELISA was analyzed as the symptom progression considering only hybrid as fixed effect since samples were taken only once for diagnosis, and the incidence of plants with positive diagnosis in the ear leaf and the penultimate leaf as response variables. Accumulated severity (AS) of each plant was calculated by summing the severity grades across timepoints (DAIs). AS was analyzed in the same way as the number of plants with positive diagnose in DAS-ELISA. In turn, to analyze the relation between progression of symptom severity and RA, accumulated severity (AS) The relation between both variables was analyzed with Spearman's rank correlation.

Yield was analyzed using a mixed linear model, with hybrid as fixed effect and block as random effect. Assumptions were validated through graphical analyses (residuals vs. predicted, normal QQ plot). Response variables were yield (qq/Ha) and relative yield (\%). The relation between yield and AS was analyzed with mixed linear models, with hybrid, AS and their interaction as fixed effects. Linear models and generalized mixed models were adjusted using nlme (Pinheiro et al. 2018) and Ime4 (Bates et al. 2015) packages of the R 
bioRxiv preprint doi: https://doi.org/10.1101/2020.05.28.120972; this version posted May 28, 2020. The copyright holder for this preprint (which

was not certified by peer review) is the author/funder, who has granted bioRxiv a license to display the preprint in perpetuity. It is made available under aCC-BY 4.0 International license.

Oleszczuk et al.

Plant Disease

Page 12 of 1

224 language (R Core Team 2018) through the statistical software interface InfoStat (Di Rienzo

225 et al. 2018). Predicted values were compared using DGC test (Di Rienzo et al. 2002), with a

226 significance level of $5 \%$ for all cases.

\section{Results}

Preference (Antixenosis to the vector Dalbulus maidis)

229 In the settling preference of adult D. maidis (Figure 1), a significant effect of hybrid and

230 timepoint factors was observed, as well as their interaction $(p<0.0001$ in all cases). The

231 hybrid effect was due to a higher number of insects settled on DK670 and DK79-10 than

232 on DK72-10 and DKB390. The timepoint effect resulted from the increase in the number of

233 insects settled on hybrids over time, as most insects settled on the cage rather than on

234 hybrids at the first timepoints (mainly in the first hour of the test). The interaction

235 between hybrid and timepoint $(p=0.0213)$ was due to insects settling more rapidly over

236 time in DK670 and DK79-10 than in DK72-10 and DKB390.

237 Figure 1.

238 The number of eggs laid by $D$. maidis females on each hybrid (Figure 2) showed a

239 significant effect of the hybrid factor $(p<0.0001)$, with a similar arrangement to Figure 1 , 240 except that only DK72-10 had significantly fewer eggs than the other hybrids.

$241 \quad$ Figure 2. 
bioRxiv preprint doi: https://doi.org/10.1101/2020.05.28.120972; this version posted May 28, 2020. The copyright holder for this preprint (which

was not certified by peer review) is the author/funder, who has granted bioRxiv a license to display the preprint in perpetuity. It is made available under aCC-BY 4.0 International license.

Oleszczuk et al.

Plant Disease

Page 13 of 1

\section{Survival (Antibiosis to the vector Dalbulus maidis)}

243 For the probability of survival of D. maidis adults over time (Figure 3), a significant effect

244 was seen for the hybrid and timepoint factors, as well as their interaction $(p<0.0001$ in all

245 cases). The hybrid effect was due to the less survival in DK72-10 compared to other

246 hybrids, and the timepoint effect resulted from the reduced survival over time in all

247 hybrids. In turn, the interaction between hybrid and timepoint is explained by the faster

248 decrease in survival in DK72-10 than in the other hybrids.

249 Figure 3.

\section{Symptom Severity (Resistance to pathogen Spiroplasma kunkelii)}

252 The incidence of plants with symptoms (Figure 4, left) showed a significant effect for

253 hybrid $(p<0.0001)$ and timepoint $(p<0.0001)$ factors, as well as their interaction

$254(p=0.0468)$. The hybrid effect was due to the incidence following the sequence DK670 =

255 DK72-10 > DK79-10 > DKB390, the timepoint effect to the increase of incidence over time,

256 and the interaction to a difference in the rate of increase of the proportion of plants with

257 symptoms, following the order DK670 > DK72-10 > DK79-10 > DKB390. For instance, 96\%

258 of plants of DK670 and $68 \%$ of plants in DK72-10 showed symptoms at 45 DAI, while only

$25912 \%$ of plants of DK79-10 showed symptoms, and no symptomatic plants were found in

260 DKB390 at this timepoint. Most plants developed symptoms after this period in these last 
bioRxiv preprint doi: https://doi.org/10.1101/2020.05.28.120972; this version posted May 28, 2020. The copyright holder for this preprint (which

was not certified by peer review) is the author/funder, who has granted bioRxiv a license to display the preprint in perpetuity. It is made available under aCC-BY 4.0 International license.

Oleszczuk et al.

Plant Disease

Page 14 of 1

261 two hybrids, with a higher rate in DK79-10 than in DKB390, which resulted in a higher final

262 (at 85 DAl timepoint) incidence in the former hybrid than in the latter hybrid.

263 Figure 4.

264 The incidence of plants with severe symptoms (Figure 4, right) showed a significant effect

265 of the hybrid $(p<0.0001)$ and timepoint $(p<0.0001)$ factors, as well as their interaction

$266(p=0.0483)$. The effect of the individual factors and their interaction was like that

267 described for incidence of plants with mild + severe symptoms (Figure 4, left). At the end

268 of the study, no DKB390 plants had severe symptoms

269 Figure 5 shows the sequence of symptom progression over time on a plant by plant basis.

270 The hybrids tested had a similar sequence of symptoms, but with differences between

271 them in the time of first detection and the following rate of progression. Symptoms

272 started mostly as leaves with red margins or chlorotic stripes, followed by stunting. In

273 some cases, symptoms were first seen as leaves with red margins followed by chlorotic

274 stripes, although this sequence was less common. Finally, no remission of symptoms was

275 seen in any case, i.e. plants showing symptoms at a certain timepoint kept displaying

276 symptoms later, either similar or more severe.

$277 \quad$ Figure 5.

279 The comparison between the presence of corn stunt measured as symptoms and diagnosis using DAS-ELISA was performed on the penultimate (upper) leaf as it was 
bioRxiv preprint doi: https://doi.org/10.1101/2020.05.28.120972; this version posted May 28, 2020. The copyright holder for this preprint (which

was not certified by peer review) is the author/funder, who has granted bioRxiv a license to display the preprint in perpetuity. It is made available under aCC-BY 4.0 International license.

Oleszczuk et al.

Plant Disease

Page 15 of 1

281 somewhat more related with symptom severity than the ear leaf, mainly in plants that

282 showed only mild symptoms after 65 DAl (Table 1). Four plants out of 100 tested

283 negatives using the ear leaf and positive with the upper leaf (Table 1). Relative

284 absorbances were almost 1 in the ear leaf in two plants (plant \#9 in DK79-10 and \#4 in

285 DK390), and so the difference in diagnosis comparing the two leaves could be related to

286 experimental error. However, there was a large difference in relative absorbance between

287 both leaves for the other two plants, likely related to lack of detection of $S$. kunkelii in the

288 ear leaf of these plants, which had displayed symptoms at the end of the test.

289 Table 1. Plants that differed in the result of the diagnosis for Spiroplasma kunkelii based

290 on the ear leaf versus the upper leaf in DAS-ELISA tests, together with progression of

291 symptom severity in these plants.

Hybrid

Plan Relative Absorbance (RA)\# $\quad$ Symptom Severity (at DAI)

\begin{tabular}{cccccccc} 
& $\mathbf{t}$ & Ear leaf & Upper leaf & $\mathbf{2 0}$ & $\mathbf{4 5}$ & $\mathbf{6 5}$ & $\mathbf{8 5}$ \\
\hline DK79-10 & 9 & 0.903 & 1.561 & 0 & 0 & 0 & 1 \\
& 11 & 0.375 & 3.005 & 0 & 0 & 1 & 3 \\
\hline DKB390 & 4 & 0.935 & 1.114 & 0 & 0 & 0 & 0 \\
& 19 & 0.126 & 1.703 & 0 & 0 & 0 & 1
\end{tabular}

292

\# RA values below 1 indicate negative diagnosis (S. kunkelii not found), and above 1

293

positive diagnosis (presence of S. kunkelii).

294 All plants of DK670 and DK72-10 had symptoms and positive diagnosis for S. kunkelii

295 (Table 2). In DK79-10, 92\% of plants had symptoms and positive diagnosis, while 8\% of 
bioRxiv preprint doi: https://doi.org/10.1101/2020.05.28.120972; this version posted May 28, 2020. The copyright holder for this preprint (which

was not certified by peer review) is the author/funder, who has granted bioRxiv a license to display the preprint in perpetuity. It is made available under aCC-BY 4.0 International license.

Oleszczuk et al.

Plant Disease

Page 16 of 1

296 plants with symptoms were diagnosed negative. These plants showed the first symptoms

297 at $85 \mathrm{DAl}$ as reddening of leaf margins (the mildest symptoms). All plants with symptoms

298 in DKB390 (64\%) tested positive. In addition, $20 \%$ of plants had positive diagnosis but no

299 visible symptoms. Relative absorbances (RA) of these plants were low in the penultimate

300 leaf (average 1.5) and lower to 1 in the ear leaf (that would have tested negative if only

301 this leaf had been used for diagnosis). The remaining $16 \%$ of plants of this hybrid had no

302 symptoms and tested negative for S. kunkelii.

303 Table 2. Proportion of plants with corn stunt symptoms and diagnosis for Spiroplasma

304 kunkelii through DAS-ELISA after forced inoculation at the four-leaf stage in four maize

305 hybrids.

\begin{tabular}{|c|c|c|c|}
\hline \multirow[b]{2}{*}{ Hybrid } & \multicolumn{2}{|l|}{ Symptoms } & \multirow[b]{2}{*}{$\%$ Plants } \\
\hline & $\#$ & Diagnosis & \\
\hline DK670 & Positive & Positive & 100 \\
\hline DK72-10 & Positive & Positive & 100 \\
\hline \multirow[t]{2}{*}{ DK79-10 } & Positive & Positive & 92 \\
\hline & & Negative & 8 \\
\hline \multirow[t]{3}{*}{ DKB390 } & Positive & Positive & 64 \\
\hline & Negative & Positive & 20 \\
\hline & & Negative & 16 \\
\hline
\end{tabular}


bioRxiv preprint doi: https://doi.org/10.1101/2020.05.28.120972; this version posted May 28, 2020. The copyright holder for this preprint (which

was not certified by peer review) is the author/funder, who has granted bioRxiv a license to display the preprint in perpetuity. It is made available under aCC-BY 4.0 International license.

Oleszczuk et al.

Plant Disease

Page 17 of 1

307 The relation between AS and RA (Table 3) revealed a low correlation (no association) for

308 all hybrids except DKB390. A positive and significant correlation was observed in this

309 hybrid, thereby showing that more severe symptoms were associated with a greater

310 accumulation of S. kunkelii.

311 Table 3. Spearman's rank correlation between corn stunt accumulated severity (AS) and

312 the accumulation of Spiroplasma kunkelii estimated as relative absorbance (RA) using

313 DAS-ELISA in four maize hybrids.

\begin{tabular}{cccc}
\hline Hybrid & $\mathbf{n}$ & r Spearman & P value\# \\
\hline DK670 & 24 & 0.0617 & 0.7747 \\
DK72-10 & 25 & -0.0739 & 0.7254 \\
DK79-10 & 25 & -0.0090 & 0.9659 \\
DKB390 & 21 & 0.5070 & 0.0190 \\
\hline 05 were considered statistically significant in Spearman's rank \\
\multicolumn{4}{c}{ correlation test. }
\end{tabular}

317 The yield of inoculated plants (Table 4) showed a significant effect for the hybrid factor

$318(p<0.0001)$ and was directly correlated to incidence and severity of symptoms (Figure 4

319 and Figure 5) in the sequence DKB390 > DK79-10 > DK72-10 > DK670. The hybrid effect

320 was also significant in terms of relative yield $(p<0.0001)$, with a sequence DKB390 > DK79-

$32110>$ DK72-10 = DK670. The sequence of hybrids in both yield and relative yield is inversely 
bioRxiv preprint doi: https://doi.org/10.1101/2020.05.28.120972; this version posted May 28, 2020. The copyright holder for this preprint (which

was not certified by peer review) is the author/funder, who has granted bioRxiv a license to display the preprint in perpetuity. It is made available under aCC-BY 4.0 International license.

Oleszczuk et al.

Plant Disease

Page 18 of 1

322 related to accumulated severity; i.e. the hybrids with the highest yield had the lowest

323 accumulated severity (AS), as shown in Table 4.

324 Table 4. Yield (qq/Ha), relative yield (RY, \%) and accumulated severity (AS, rate) of four

325 maize hybrids inoculated with Spiroplasma kunkelii.

\begin{tabular}{ccccccc}
\hline Hybrid & \multicolumn{2}{c}{ Yield (qq/Ha) $^{2}$} & RY (\%) & & AS (Rate) \\
\hline DKB390 & 127.1 & A & 82.8 & A & 1.3 & D \\
DK79-10 & 92.4 & B & 50.2 & B & 3.0 & C \\
DK72-10 & 67.4 & C & 40.2 & C & 5.9 & B \\
DK670 & 46,2 & D & 37.1 & C & 8.0 & A
\end{tabular}

\# RY. Relative yield to non-inoculated plants.

$327 *$ AS. Sum of rates in four timepoints (maximum value of 16, as if severity rating was of 4 in every timepoint).

329 Values sharing the same letter (within each column) are not statistically different for a 5\% 330 significance level. Values with the same letter are not significantly different according to contrasts in the mixed model test $(\alpha=0.05)$.

332 The effect of symptom severity on yield (Figure 6) was compared in two sections 333 considering that AS was below 2 in DKB390. The first section analyzed the four hybrids in 334 an AS from 0 to 2, and the second section compared the three remaining hybrids 335 (excluding DKB390) in an AS from 3 to 7. In the first section, there was a significant effect 336 for the hybrid $(p=0.0013)$ and AS $(<0.0001)$ factors, as well as their interaction $(p=0.0008)$.

337 The hybrid effect was due to the higher yield of DKB390, the AS effect to decreased yield 
bioRxiv preprint doi: https://doi.org/10.1101/2020.05.28.120972; this version posted May 28, 2020. The copyright holder for this preprint (which

was not certified by peer review) is the author/funder, who has granted bioRxiv a license to display the preprint in perpetuity. It is made available under aCC-BY 4.0 International license.

Oleszczuk et al.

Plant Disease

Page 19 of 1

338

339

340

341

342

343

344

345

346

347

348

349

350

351

352

353

354

355

356

357

358

resulting from the increase in AS, and the interaction to DKB390 having a higher yield than the others in AS of 0-1, without significant differences in an AS of 2. The coefficient of AS factor was -9.8 , so was lowered by $9.8 \mathrm{qq} / \mathrm{Ha}$ for each unit of increase in AS. In the section of AS 3-7, only AS had a significant effect $(p<0.0001)$, but not the hybrid $(p=0.4345)$ nor the interaction between both factors $(p=0.3428)$. The coefficient of the AS factor was -9.3 for this case, indicating that for each unit of increase in AS yield was reduced by $9.3 \mathrm{qq} / \mathrm{Ha}$.

Figure 6.

\section{Discussion}

Findings from this research prove that hybrids differ in both their level of resistance to corn stunt as well as the target organisms (either the insect vector or the pathogen) and the mechanisms of such resistance. Differences among hybrids were found in the level of antixenosis to $D$. maidis, resulting in decreased settling preference of $D$. maidis females, like findings in rice with Nephotettix virescens (Cheng and Pathak 1972; Heinrichs and Rapusas 1983a) and Sogatella furcifera (Khan and Saxena 1985; Ye and Saxena 1990), and in oats with Delphacodes kuscheli (Costamagna et al. 2005), where settling preference was also seen as early as six hours from exposure to plants. Our results suggest that maize hybrids DK72-10 and DKB390 negatively interfered with host acceptance by vector $D$. maidis, and hence may decrease the inoculation efficiency of the pathogen S. kunkelii to them, as such efficiency increases with the interval of insect-plant interaction (Alivizatos and Markham 1986). Settling preference tests using inoculative insects may confirm or rule out this hypothesis, which may be a future line of research. 
bioRxiv preprint doi: https://doi.org/10.1101/2020.05.28.120972; this version posted May 28, 2020. The copyright holder for this preprint (which

was not certified by peer review) is the author/funder, who has granted bioRxiv a license to display the preprint in perpetuity. It is made available under aCC-BY 4.0 International license.

Oleszczuk et al.

Plant Disease

Page 20 of 1

Only DK72-10 showed antibiosis by reducing survival of $D$. maidis relative to other hybrids.

An effect of antibiosis was also found in rice against N. virescens (Cheng and Pathak 1972;

361

Heinrichs and Rapusas 1983a), N. cincticeps (Kawabe 1985), Nilaparvata lugens (Sogawa

and Pathak 1970; Ye and Saxena 1990) and S. furcifera (Heinrichs and Rapusas 1983b;

Khan and Saxena 1985). However, the antibiosis against $D$. maidis seen in this study was

lower in absolute terms compared to other cases. For example, survival of $N$. virescens adults (Cheng and Pathak 1972; Ye and Saxena 1990) and S. furcifera (Heinrichs and

371 tested here.

377 probability of detection of $S$. kunkelii was higher in the apex of the plant, which may be

378 explained by the fact that $S$. kunkelii moves with photosynthates to the actively growing

379 apical regions of the plant, or that these parts promote the multiplication of S. kunkelii. In 
bioRxiv preprint doi: https://doi.org/10.1101/2020.05.28.120972; this version posted May 28, 2020. The copyright holder for this preprint (which

was not certified by peer review) is the author/funder, who has granted bioRxiv a license to display the preprint in perpetuity. It is made available under aCC-BY 4.0 International license.

Oleszczuk et al.

Plant Disease

Page 21 of 1

381 kunkelii, but some DK79-10 plants that showed their first symptoms in the last timepoint

382 were tested negatives. This may be due to the irregular distribution of $S$. kunkelii within

383 the various plant organs and at low concentrations while displaying the first symptoms,

384 thereby resulting in a negative diagnosis (Gussie et al. 1995).

Most plants in DKB390 (64\%) showed symptoms and tested positive for S. kunkelii, but 20

$\%$ of plants showed no symptoms despite a positive diagnosis, and $16 \%$ of plants had no

symptoms and a tested negative. On one hand, the presence of plants without symptoms

but with positive diagnosis agrees with reports from Gussie et al. (1995), in which S.

kunkelii is detected $10-30$ days before symptom onset. Here, these plants might have shown symptoms in a later timepoint, although the test was completed when all hybrids

were at physiological maturity. On the other hand, the presence of plants without

symptoms and negative diagnosis may be due to: a) a failure in methodology, which

seems unlikely because inoculation efficiency was $100 \%$ in other hybrids; b) antibiosis

and/or antixenosis to $D$. maidis, lowering the length of insect-plant interaction and hence

reducing inoculation efficiency of S. kunkelii, although DK72-10 had similar antixenosis and

more antibiosis than DKB390 and all of its plants were inoculated, and in similar 
bioRxiv preprint doi: https://doi.org/10.1101/2020.05.28.120972; this version posted May 28, 2020. The copyright holder for this preprint (which

was not certified by peer review) is the author/funder, who has granted bioRxiv a license to display the preprint in perpetuity. It is made available under aCC-BY 4.0 International license.

Oleszczuk et al.

Plant Disease

Page 22 of 1

403

404 405 rather than the insect vector.

406

407

408

409

410

411

412

413

414

415

416

417

418

419

420

421

422

423

al. 2002) and for RTBV and RTSV in rice (Azzam and Chancellor 2002; Hibino et al. 1987), whom suggest that the target of resistance of some plant genotypes is the pathogen itself

Hybrids differed in symptom progression, including initial detection, subsequent progress and final severity. Symptoms appeared earlier and progressed faster in susceptible vs. resistant hybrids as reported before (Massola Junior et al. 1999a; Scott et al. 1977). Based on these characters, the order of resistance to S. kunkelii was defined as DKB390 > DK7910 > DK72 -10 > DK670. Hybrids from temperate areas, DK670 and DK72-10, were highly susceptible to S. kunkelii, as symptoms developed early (although later in DK72-10) and progressed rapidly reaching a high proportion of plants with severe damage and low yield. Symptoms in DK79-10 appeared later and progressed slowly, leading to a lower rate of plants with severe symptoms and intermediate yield. Finally, DKB390 was the most resistant hybrid to S. kunkelii, as some plants had no symptoms and no pathogen was found in them, others had no symptoms despite the presence of S. kunkelii, and others developed late-onset mild symptoms, resulting in the highest yield. These results confirm that higher yield reductions occur when symptoms appear early and progress rapidly as discussed before (Hidalgo et al. 1998; Massola Junior et al. 1999b; Oliveira et al. 2002; Scott et al. 1977), leading to two major concepts related to the control of this disease: a) the need to control corn stunt at early growth stages, way before symptom appearance, b) to identify resistant genotypes, rating symptom progression may be more useful than a single assessment at a specific timepoint. In this sense, an aspect to consider is that the 
bioRxiv preprint doi: https://doi.org/10.1101/2020.05.28.120972; this version posted May 28, 2020. The copyright holder for this preprint (which

was not certified by peer review) is the author/funder, who has granted bioRxiv a license to display the preprint in perpetuity. It is made available under aCC-BY 4.0 International license.

Oleszczuk et al.

Plant Disease

Page 23 of 1

424 lack of a complete correlation between symptom presence and diagnosis suggests that

425 both are necessary to properly characterize genotypes resistant to corn stunt disease.

426 Yield loss caused by S. kunkelii ranging from $20 \%$ to $63 \%$ with final incidence rates

427 between 63 and $100 \%$ are within the range previously reported (Hao and Pitre 1970;

428 Hidalgo et al. 1998; Hruska and Gomez Peralta 1997; Massola Junior et al. 1999b; Scott et

al. 1977; Virla et al. 2004). These authors also discussed that genotypes with similar levels

430 of incidence and severity of symptoms can achieve different yields (Hidalgo et al. 1998;

431 Oliveira et al. 2002; Scott et al. 1977;). This has been described as host tolerance, or the

432 ability to obtain yield despite the damage caused by corn stunt. However, this response

433 was not seen in this study, as yield reductions were directly related to the incidence and

434 severity of symptoms.

435 No consistent relation was found between the accumulation of $S$. kunkelii and symptom

436 severity, both intra- and inter hybrids. This contradicts other results (Caro et al. 2008;

437 Gussie et al. 1995; Virla et al. 2004) reporting a higher accumulation in plants with severe

438 symptoms but is consistent with findings in rice (Shibata et al. 2007), where no differences

439 were observed in the accumulation of viruses causing Rice Tungro Disease among varieties

440 differing in resistance or among plants with varying severity. The absence of a correlation

441 in this work may be due to the method used (DAS-ELISA), which was performed here

442 without a dilution curve to estimate the concentration of $S$. kunkelii. In turn, new methods

443 to estimate pathogen accumulation (Okuda et al. 2019) found this relation for viruses

444 causing Rice Tungro Disease, so therefore may be useful to characterize the dynamics of $S$.

445 kunkelii accumulation in maize hybrids differing in resistance to corn stunt. 
bioRxiv preprint doi: https://doi.org/10.1101/2020.05.28.120972; this version posted May 28, 2020. The copyright holder for this preprint (which

was not certified by peer review) is the author/funder, who has granted bioRxiv a license to display the preprint in perpetuity. It is made available under aCC-BY 4.0 International license.

Oleszczuk et al.

Plant Disease

Page 24 of 1

446 This work identified resistance mechanisms to the vector D. maidis and to the pathogen $S$.

447 kunkelii as components of corn stunt pathosystem. Hybrids differed in the level of

448 resistance and target organisms of such resistance. DK72-10 showed antixenosis and

449 antibiosis to D. maidis, DK79-10 was resistant to S. kunkelii and DKB390 expressed

450 antixenosis to $D$. maidis and resistance to $S$. kunkelii. More than one mechanism and

451 target organism (vector or pathogen) of resistance were identified with this strategy,

452 which therefore provides the potential to combine them to obtain even more resistant

453 hybrids. This is an advantage of this type of testing over natural infestations, where the

454 observed response (incidence or severity of symptomatic plants) does not allow to

455 differentiate between these foregoing factors. In summary, the presence of resistant

456 hybrids combined with the use of an effective method for differentiation may facilitate

457 the selection of hybrids capable of reducing the negative impact of corn stunt.

\section{Acknowledgements}

459 We thank Mariana Ferrer for his assistance in setting up insect survival and symptom 460 progression experiments.

461 This research did not receive any specific grant from funding agencies in the public, 462 commercial, or not-for-profit sectors.

References

464 Alstatt, G. 1945. A new corn disease in the Rio Grande Valley. Plant Disease. Rep. 29: 533465534. 
bioRxiv preprint doi: https://doi.org/10.1101/2020.05.28.120972; this version posted May 28, 2020. The copyright holder for this preprint (which

was not certified by peer review) is the author/funder, who has granted bioRxiv a license to display the preprint in perpetuity. It is made available under aCC-BY 4.0 International license.

Oleszczuk et al.

Plant Disease

Page 25 of 1

466

467

468

469

470

471

472

473

474

475

476

477

478

479

480

481

482

483

484

485

486

487

Alivizatos, A.S., and Markham, P.G. 1986. Acquisition and transmission of corn stunt spiroplasma by its leafhopper vector Dalbulus maidis. Ann. Appl. Biol. 108: 535-544.

Azzam, O., and Chancellor, T. 2002. The Biology, Epidemiology, and Management of Rice Tungro Disease in Asia. Plant Disease 86: 88-100.

Bates, D., Maechler, M., Bolker, B., and Walker, S. 2015. Fitting Linear Mixed-Effects Models Using Ime4. Journal of Statistical Software 67: 1-48.

Bajet, N.B., and Renfro, B.L. 1989. Occurrence of corn stunt spiroplasma at different elevations in Mexico. Plant Disease 73: 926-930.

Bradfute, O.E., Tsai, J.H., and, Gordon D.T. 1981. Corn Stunt Spiroplasma and viruses associated with a maize disease in Southern Florida. Plant Disease 65: 837-841.

Carloni, E. 2010 Características de corn stunt spiroplasma en Argentina. M Sc. Tesis. Facultad de Ciencias Agropecuarias. Universidad Nacional de Córdoba.

Carloni, E., Carpane, P., Paradell, S., Laguna, I., and Giménez Pecci, M.P. 2013. Presence of Dalbulus maidis (Hemiptera: Cicadellidae) and of Spiroplasma kunkelii in the Temperate Region of Argentina. J. Econ. Entomol. 106: 1574-1581.

Carloni, E., Virla, E., Paradell, S., Carpane, P., Nome, C., Laguna, I., and Giménez Pecci, M.P. 2011. Exitianus obscurinervis (Hemiptera: Cicadellidae), a new experimental vector of Spiroplasma kunkelii. J. Econ. Entomol. 104: 1793-1799.

Caro, L.A., Giménez Pecci, M.P., and Laguna, I.G. 2008. Susceptibilidad de 3 genotipos de maíz a $D$. maidis y a Spiroplasma kunkelii evaluada mediante variables fisiológicas y de rendimiento. $1^{\circ}$ Congreso Argentino de Fitopatología, Córdoba, 28-30 mayo. Resúmenes (ISBN 978-987-24373-0-51): 336. 
bioRxiv preprint doi: https://doi.org/10.1101/2020.05.28.120972; this version posted May 28, 2020. The copyright holder for this preprint (which

was not certified by peer review) is the author/funder, who has granted bioRxiv a license to display the preprint in perpetuity. It is made

Oleszczuk et al.

Plant Disease

Page 26 of 1

488 Caro, L.A., Bisonard, E.M., Laguna, I.G., and Giménez Pecci, M.P. 2009. Efecto del corn

489 stunt spiroplasma (CSS) sobre parámetros de rendimiento de tres genotipos de maíz. XIII

490 Jornadas Fitosanitarias Argentinas, Termas de Río Hondo, Santiago del Estero, 30 Sept, 1

491 y 2 oct 2009.

492 Carpane, P., Laguna, I.G., Virla, E., Paradell, S., and Giménez Pecci, M.P. 2006.

493 Experimental transmission of corn stunt spiroplasma present in different regions of

494 Argentina. Maydica 51: 461-468.

495 Carpane, P. 2007. Host resistance and diversity of Spiroplasma kunkelii as components of 496 corn stunt disease. PhD. Thesis. Department of Entomology and Plant Pathology.

497 Oklahoma State University. Stillwater, OK., USA.

498 Carpane, P., Melcher, U., Wayadande, A., Giménez Pecci, M.P., Laguna, I.G., Dolezal, W., 499 and Fletcher, J. 2013. An analysis of the genomic variability of the phytopathogenic 500 mollicute Spiroplasma kunkelii. Phytopathology 103: 129-134.

501 Castañón, G., Hidalgo, H., and Jeffers, D. 2003. Heterosis en siete líneas de maíz para 502 tolerancia al achaparramiento y rendimiento de grano.

503 Cheng, C.H., and Pathak, M.D. 1972. Resistance to Nephotettix virescens in rice varieties. J. $504 \quad$ Econ. Entomol. 65: 1148-1153.

505 Costamagna, A.C., Remes Lenicov, A.M.M., and Zanelli, M. 2005. Maize and oat 506 antixenosis and antibiosis against Delphacodes kuscheli (Homoptera: Delphacidae), 507 vector of "Mal de Rio Cuarto" of maize in Argentina. J. Econ. Entomol. 98: 1374-1381. 
bioRxiv preprint doi: https://doi.org/10.1101/2020.05.28.120972; this version posted May 28, 2020. The copyright holder for this preprint (which

was not certified by peer review) is the author/funder, who has granted bioRxiv a license to display the preprint in perpetuity. It is made available under aCC-BY 4.0 International license.

Oleszczuk et al.

Plant Disease

Page 27 of 1

508

509

510

511

512

513

514

515

516

$517 \quad$ Fitopatol. Brasileira 28: 280.

518 Giménez Pecci, M.P., Laguna, I.G., Carpane, P.D., Carloni, E., and Murúa, L. 2005.

519 Dispersión e incidencia del corn stunt spiroplasma en el cultivo de maíz en diferentes

520 áreas de Argentina. XIII Congreso Latinoamericano de Fitopatología y III Taller de la

521 Asociación Argentina de Fitopatólogos. 19-22 abril. Córdoba, Argentina Res 477.

522 Giménez Pecci, M.P., Laguna, I.G., Ávila, A.O., Remes Lenicov, A.M., Virla, E., Borgogno, C.,

523 Nome, C.F., and Paradell, S. 2002. Difusión del corn stunt spiroplasma del maíz

524 (Spiroplasma kunkelii) y del vector (Dalbulus maidis) en la República Argentina. Revista

525 de la Facultad de Agronomía de La Plata 105: 1-8.

526 Gómez, L.G. 2012. Cap. II. El maíz en áreas del trópico. Pg. 25-30. En: Enfermedades del

527 maíz producidas por virus y mollicutes en Argentina. Editores: Giménez Pecci, MP,

528 Laguna, IG, Lenardón SL. Ediciones INTA (ISBN: 978-987-679-116-8). 
bioRxiv preprint doi: https://doi.org/10.1101/2020.05.28.120972; this version posted May 28, 2020. The copyright holder for this preprint (which

was not certified by peer review) is the author/funder, who has granted bioRxiv a license to display the preprint in perpetuity. It is made available under aCC-BY 4.0 International license.

Oleszczuk et al.

Plant Disease

Page 28 of 1

529 Gussie, J.S., Fletcher, J., and Claypool, P.L. 1995. Movement and multiplication of

530 Spiroplasma kunkelii in corn. Phytopathology 85: 1093-1098.

531 Hao, G., and Pitre, H. 1970. Relationship of Vector Numbers and Age of Corn Plants at

532 Inoculation to Severity of Corn Stunt Disease. Journal of Economic Entomology 63: 924-

533927.

534 Heinrichs, E.A., and Rapusas, H. 1983a. Correlation of resistance to the green leafhopper,

535 Nephotettix virescens (Homoptera: Cicadellidae) with tungro virus infection in rice

536 varieties having different genes for resistance. Environ. Entomol. 12: 201-205.

537 Heinrichs, E.A., and Rapusas, H. 1983b. Levels of resistance to the whitebacked

538 planthopper, Sogatella furcifera (Homoptera: Delphacidae), in rice varieties with

539 different resistance genes. Environ. Entomol. 12: 1793-1797.

540 Hibino, H., Tiongco, E.R., Cabunagan, R.C., and Flores, Z.M. 1987. Resistance to rice

541 tungro-associated viruses in rice under experimental and natural conditions.

$542 \quad$ Phytopathology 77: 871-875.

543 Hidalgo, H., Jeffers, D., and Rodríguez, F. 1998. Resistencia al achaparramiento del maíz

544 mediante infestaciones de Dalbulus maidis en maíz. Agronomía Mesoamericana 9: 119-

545124.

546 Hogenboom, N.G. 1993. Economic importance of breeding for disease resistance, pp. 5-9.

547 In T. Jacobs and J. Parlevliet [eds.], Durability of disease resistance. Kluwer Academic

$548 \quad$ Publishers, Boston.

549 Hruska, A.J., Gladstone, S.M., and Obando, R. 1996. Epidemic roller coaster: maize stunt

550 disease in Nicaragua. Am. Entomology 42: 248-252. 
bioRxiv preprint doi: https://doi.org/10.1101/2020.05.28.120972; this version posted May 28, 2020. The copyright holder for this preprint (which

was not certified by peer review) is the author/funder, who has granted bioRxiv a license to display the preprint in perpetuity. It is made available under aCC-BY 4.0 International license.

Oleszczuk et al.

Plant Disease

Page 29 of 1

551 Hruska, A.J, and Gómez Peralta, M. 1997. Maize Response to Corn Leafhopper

552 (Homoptera: Cicadellidae) Infestation and Achaparramiento Disease. J. Econ. Entomol.

$55390: 604-610$.

554 Kawabe, S. 1985. Mechanism of varietal resistance to the rice green leafhopper 555 (Nephotettix cincticeps Uhler). JARQ 19: 115-124.

556 Khan, Z. R., and Saxena, R.C. 1985. Behavioral and physiological responses of Sogatella

557 furcifera (Homoptera: Delphacidae) to selected resistant and susceptible rice cultivars. J.

$558 \quad$ Econ. Entomol. 78: 1280-1286.

559 Kunkel, L. 1946. Leafhopper transmission of corn stunt. PNAS 32: 246-247.

560 Lenardón, S.L., Laguna, I.G., Gordon, D.T., Truol, G.A., Gomez, J., and Bradfute, O.E. 1993.

561 Identification of Corn Stunt Spiroplasma in maize from Argentina. Plant Disease 77: 100.

562 Massola Júnior, N.S., Bedendo, I.P., Amorim, L., and Lopes, J.R.S. 1999a. Fitoplasma e

563 espiroplasma em milho: multiplicação e efeito na produção de genótipos resistente e 564 suscetível. Summa Phytopathologica 25: 356-359.

565 Massola Júnior, N.S., Bedendo, I.P., Amorim, L., and Lopes, J.R.S. 1999b. Effects of the

566 inoculation time on corn with Spiroplasma kunkelii on yield components. Fitopatologia

567 Brasileira 24: 571-573.

568 Mendoza, M., López, A., Rodríguez, S., Oyervides, García A., De León, C., and Jeffers, D.

569 2002. Acción génica de la resistencia al achaparramiento del maíz causado por

570 espiroplasma, fitoplasmas y virus. Revista Mexicana de Fitopatología 20: 13-17.

571 Nault, L.R. 1980. Maize bushy stunt and corn stunt: A comparison of disease symptoms, 572 pathogen host ranges, and vectors. Phytopathology 70: 659-662. 
bioRxiv preprint doi: https://doi.org/10.1101/2020.05.28.120972; this version posted May 28, 2020. The copyright holder for this preprint (which

was not certified by peer review) is the author/funder, who has granted bioRxiv a license to display the preprint in perpetuity. It is made available under aCC-BY 4.0 International license.

Oleszczuk et al.

Plant Disease

Page 30 of 1

573 Nault, L.R. 1990. Evolution of an insect pest: maize and the corn leafhopper, a case study.

$574 \quad$ Maydica 35: 165-175.

575 Okuda, M., Shiba, T., Hirae, M., Masunaka, A, and Takeshita, M. 2019. Analysis of

576 symptom development in relation to quantity of Rice stripe virus in rice (Oryza sativa) to

577 simplify evaluation of resistance. Phytopathology 109: 701-707.

578 Oliveira, E., Waquil, J.M., Fernandes, F.T., Paiva, E., Resende, R., and Kitajima, W.E. 1998.

579 Enfezamento pálido e enfezamento vermelho na cultura do milho no Brasil Central.

$580 \quad$ Fitopatologia Brasileira 23: 45-47.

581 Oliveira, E., Oliveira, C., Souza, I., Magalhaes, P. and Cruz, I. 2002. Enfezamentos em milho:

582 expressão de sintomas foliares, deteç̧ão dos molicutes e interações com genótipos.

583 Revista Brasileira de Milho e Sorgo 1: 53-62.

584 Oliveira, E., Resende, R., Gimenez Pecci, M.P., Laguna, I.M., Herrera, P., and Cruz, I. 2003.

585 Incidência de viroses e enfezamentos e estimativa de perdas causadas por molicutes em

586 milho no Paraná. Pesquisa Agropecuária Brasileira 38: 19-25.

587 Paradell, S., Virla, E., and Toledo, A. 2001. Leafhoppers species richness and abundance on 588 corn crops in Argentina (Insecta-Hemiptera-Cidadellidae). Bol. Sanidad Vegetal y Plagas $589 \quad 27: 465-474$.

590 Pinheiro, J., Bates, D., DebRoy, S., Sarkar, D., and R Core Team. 2018. nlme: Linear and

591 Nonlinear Mixed Effects Models. R package version 3.1-137. URL: https://CRAN.R592 project.org/package=nlme.

$593 \mathrm{R}$ Core Team. 2018. R: A language and environment for statistical computing. R 594 Foundation for Statistical Computing, Vienna, Austria. https://www.R-project.org/. 
bioRxiv preprint doi: https://doi.org/10.1101/2020.05.28.120972; this version posted May 28, 2020. The copyright holder for this preprint (which

was not certified by peer review) is the author/funder, who has granted bioRxiv a license to display the preprint in perpetuity. It is made available under aCC-BY 4.0 International license.

Oleszczuk et al.

Plant Disease

Page 31 of 1

595 Rezaul Karim, A., and Saxena, R.C. 1991. Feeding behavior of three Nephotettix species

596 (Homoptera: Cicadellidae) on selected resistant and susceptible rice cultivars, wild rice,

597 and graminaceous weeds. J. Econ. Entomol. 84: 1208-1215.

598 Rodriguez, E.A., and Preciado, R.E. 1988. Obtención de variedades resistentes o tolerantes

599 a enfermedades foliares y de mazorca. Primera Reunión Científica y Agropecuaria.

600 Centro de Investigaciones Forestales y Agropecuarias de Veracruz. INIFAPCIRGOC. MEX.

$601 \quad$ p. 17.

602 Saxena, R.C. 1987. Antifeedants in tropical pest management. Insect Sci. Application 8:

$603 \quad 731-736$.

604 Scott, G., and Rosenkranz, E. 1977. Effectiveness for Recurrent Selection for Corn Stunt

605 Resistance in a Maize Variety. Crop Science 14: 758-760.

606 Scott, G., Rosenkranz, E., and Nelson, L. 1977. Yield losses of corn due to corn stunt

607 disease complex. Agronomy Journal 69: 92-94.

608 Shibata, Y., Cabunagan, R.C., Cabauatan, P.Q., and Choi, I.R. 2007. Characterization of

609 Oryza rufipogon-derived resistance to tungro disease in rice. Plant Disease 91: 1386-

6101391.

611 Sogawa, K., and Pathak, M.D. 1970. Mechanisms of brown planthopper resistance in

612 Mudgo variety of rice (Hemiptera: Delphacidae). Appl. Entomol. Zool. 5: 145-158.

613 Sutula, C., Gillet, J., Morrisey, S., and Ramsdell, D. 1986. Interpreting ELISA data and 614 establishing the positive-negative threshold. Plant Disease 70: 722-726.

615 Venables, W.N., and Ripley, B.D. 2002. Modern Applied Statistics with S. Fourth Edition. 616 Springer, New York. ISBN 0-387-95457-0. 
bioRxiv preprint doi: https://doi.org/10.1101/2020.05.28.120972; this version posted May 28, 2020. The copyright holder for this preprint (which

was not certified by peer review) is the author/funder, who has granted bioRxiv a license to display the preprint in perpetuity. It is made available under aCC-BY 4.0 International license.

Oleszczuk et al.

Plant Disease

Page 32 of 1

617 Virla, E., Remes Lenicov, A., and Paradell, S. 1990. Presencia de Dalbulus maidis sobre maíz

618 y teosinte en la República Argentina (Insecta - Homoptera - Cicadellidae). Rev. Fac. de

619 Agr. La Plata. 66/67: 23-30.

620 Virla, E., Paradell, S., and Diez, P. 2003. Estudios bioecológicos sobre la chicharrita del maíz

621 Dalbulus maidis (Insecta - Cicadellidae) en Tucumán (Argentina). Bol. San. Veg. Plagas

$622 \quad 29: 17-25$.

623 Virla, E.G., Díaz, C.G., Carpane, P.D., Laguna, I.G., Ramallo, J., Gómez, G.L., and Giménez

624 Pecci, M.P. 2004. Evaluación preliminar de la disminución en la producción de maíz

625 causada por el "Corn stunt spiroplasma" (CSS) en Tucumán, Argentina. Bol. San. Veg.

626 Plagas 30: 257-267.

627 Whitcomb, R.F., Chen, T.A., Williamson, D.L., Liao, C., Tully, J.G., Bove, J.M., Mouches, C.,

628 Rose, D.L., Coan, M.E., and Clark, T.B. 1986. Spiroplasma kunkelii sp. nov.:

629 characterization of the etiological agent of corn stunt disease. J. Syst. Bacteriol. 36: 170-

630178.

631 Ye, Z.H., and Saxena, R.C. 1990. Resistance to Whitebacked Planthopper in elite lines of 632 cultivated $X$ wild rice crosses. Crop Sci. 30: 1178-1182. 


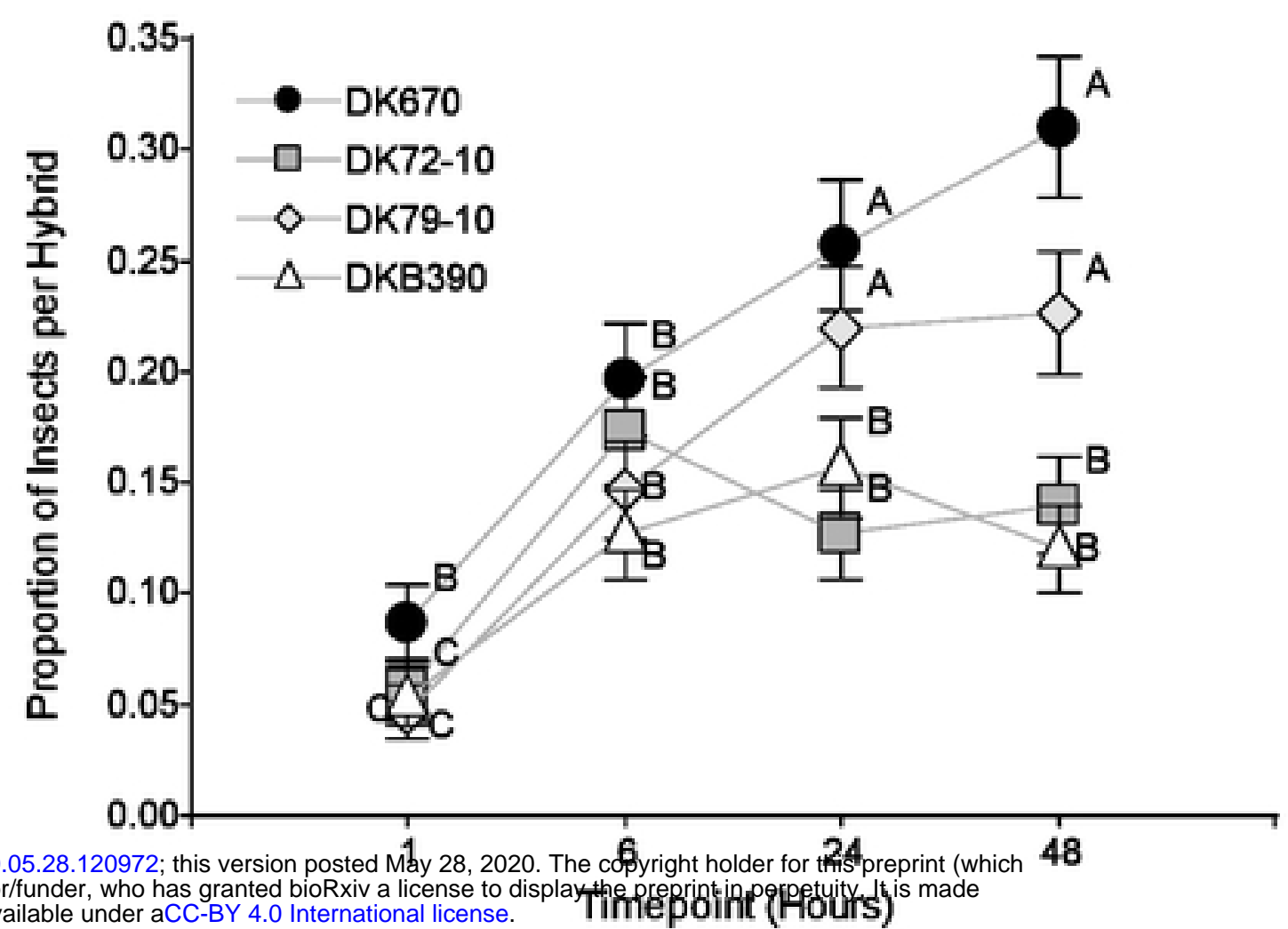

bioRxiv preprint doi: https://doi.org/10.1101/2020.05.28.120972; was not certified by peer review) is the author/funder, who has granted bioRxiv a license to display thimprepringiniperpetuity - Jb is made

Figure 1. Proportion of Dalbulus maidis individuals settled on different hybrids over time.

Values sharing the same letter are not statistically different for a $5 \%$ significance level. Values with the same letter are not significantly different according to contrasts in the multinomial test $(\alpha=0.05)$. Bars indicate standard error of the mean.

Figure 1 


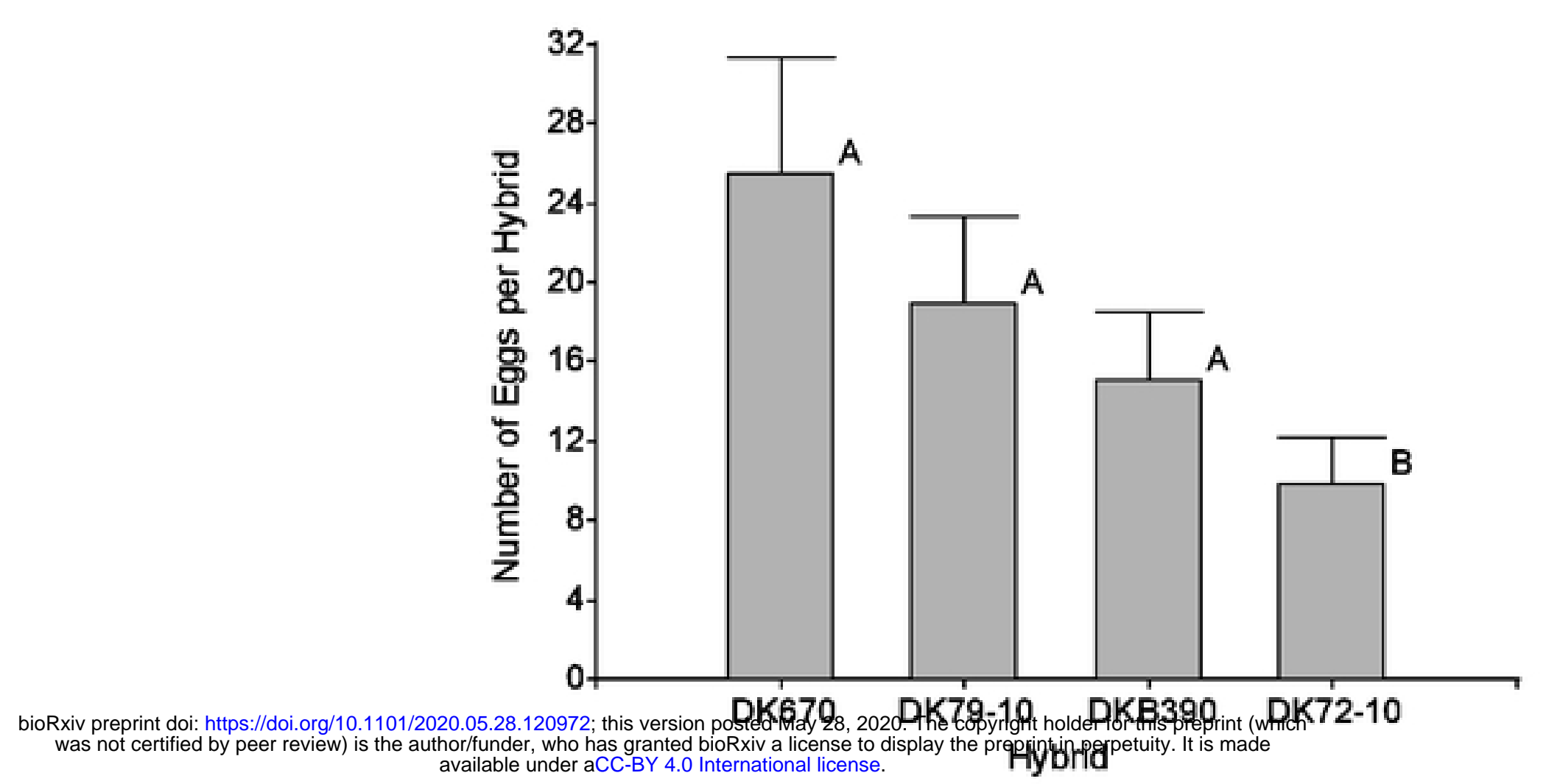

Figure 2. Number of eggs oviposited by Dalbulus maidis females during $\mathbf{4 8}$ hours in four maize hybrids. Values with the same letter are not significantly different according to contrasts in the mixed model test $(\alpha=0.05)$. Bars indicate standard error of the mean.

Figure 2 


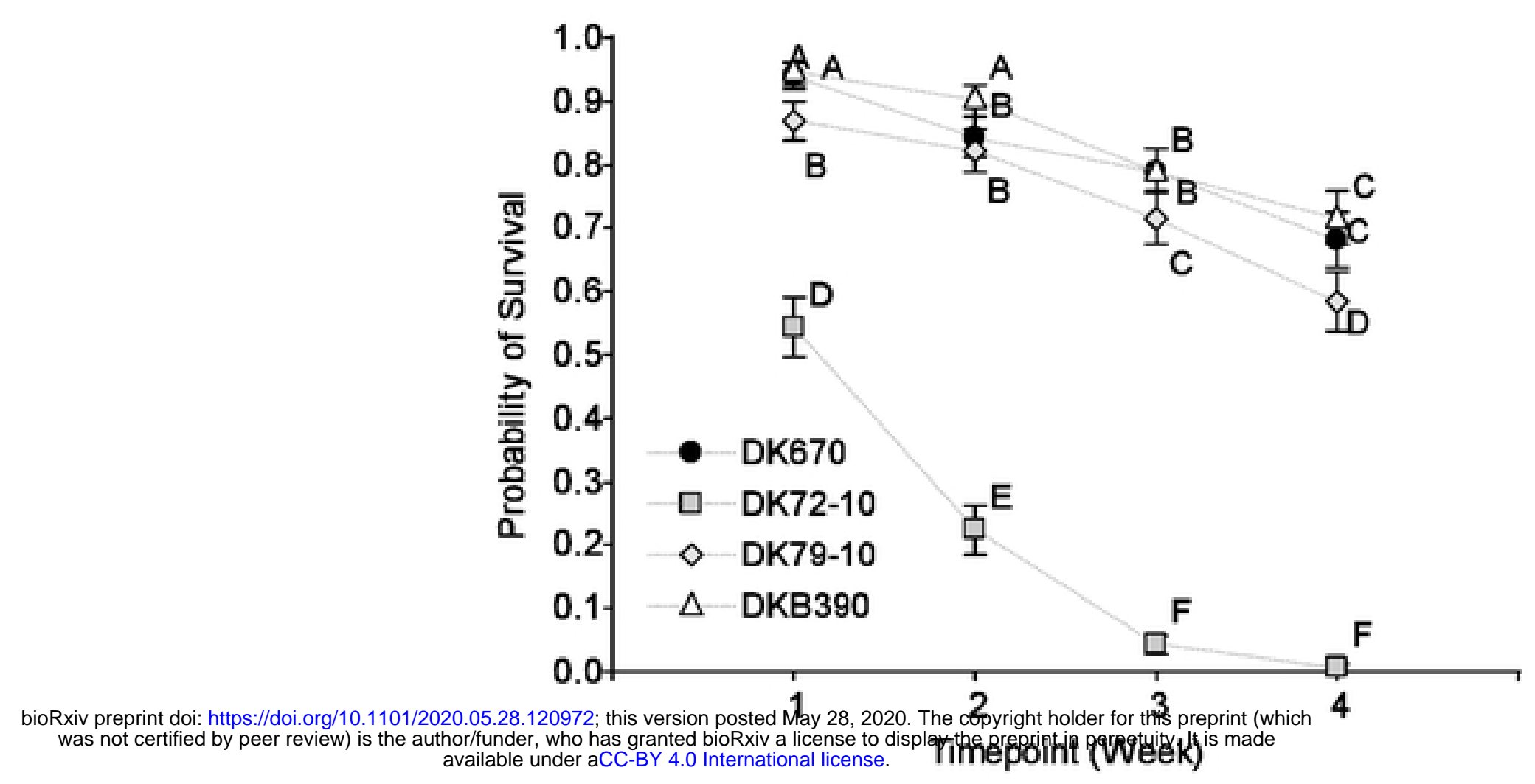

Figure 3. Probability of survival of Dalbulus maidis adults over time in four maize hybrids.

Values sharing the same letter are not statistically different for a $5 \%$ significance level. Values with the same letter are not significantly different according to contrasts in the mixed model test $(\alpha=0.05)$. Bars indicate standard error of the mean.

Figure 3 

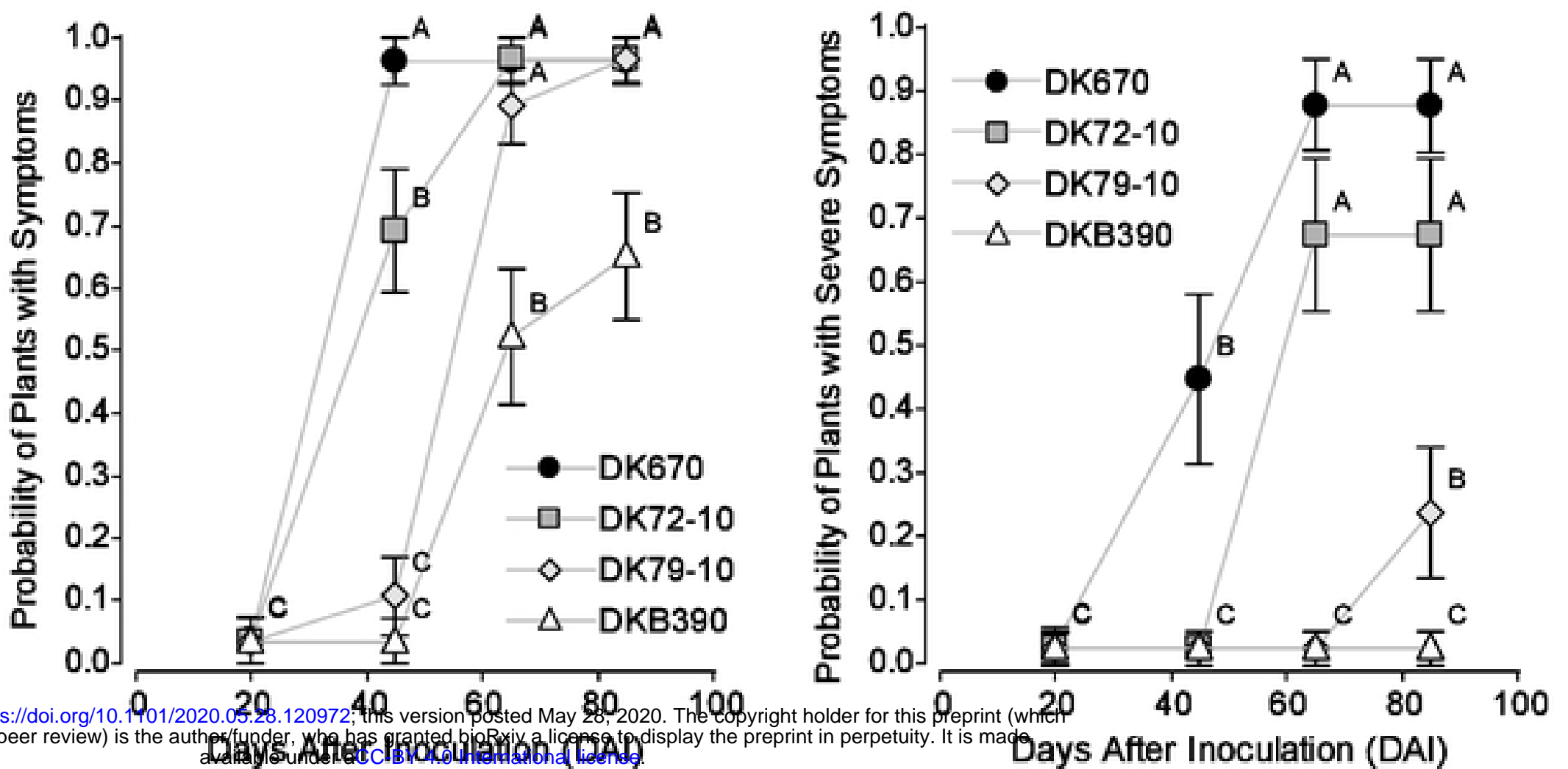

Figure 4. Incidence (Probability) of plants with symptoms (left) and with severe symptoms (right) after forced inoculation of the pathogen Spiroplasma kunkelii to four maize hybrids.

Values sharing the same letter (within each panel) are not statistically different for a $5 \%$ significance level. Values with the same letter are not significantly different according to contrasts in the mixed model test $(\alpha=0.05)$. Bars indicate standard error of the mean. 


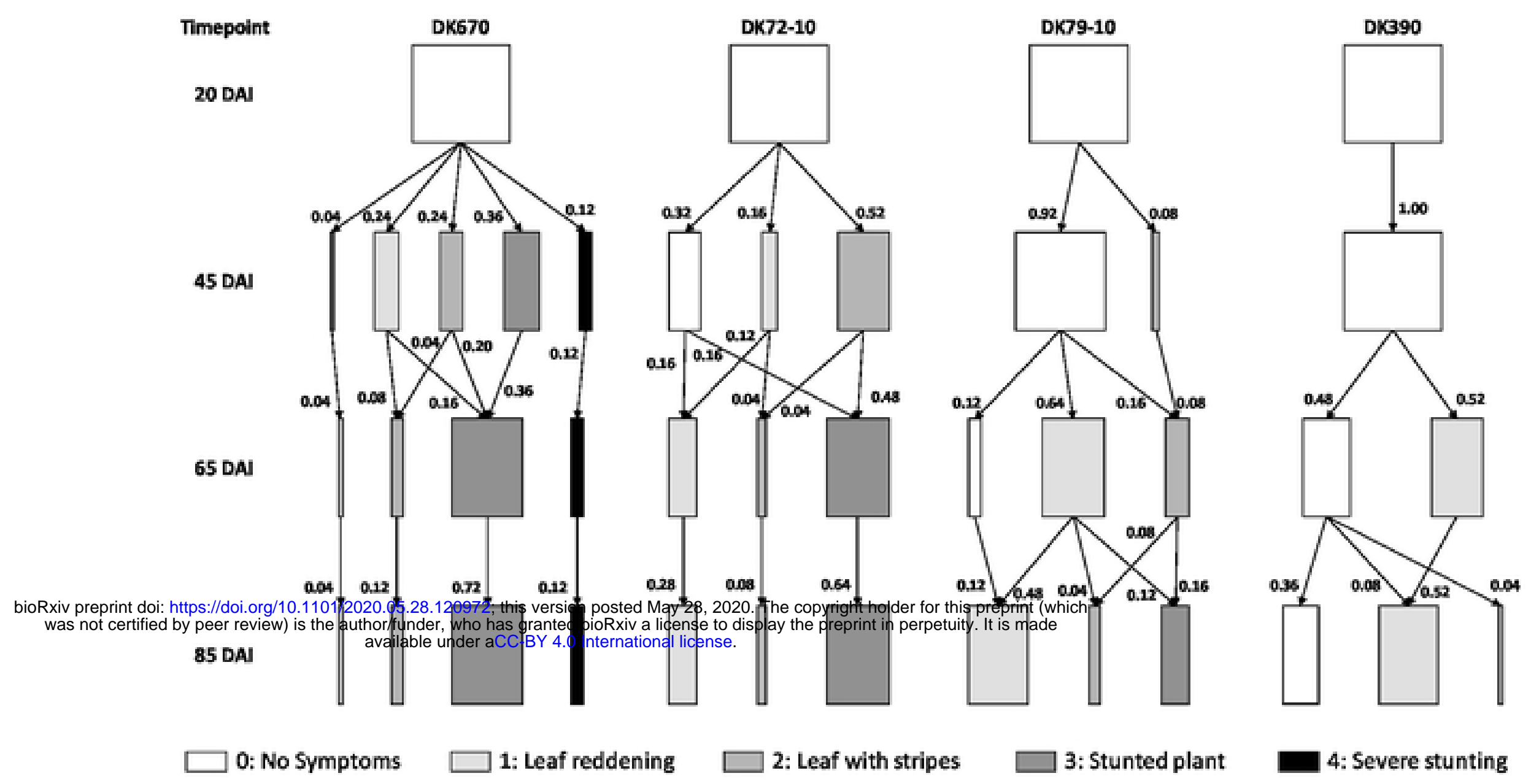

Figure 5. Kinematic diagram of the sequence of corn stunt disease symptom incidence and severity in four maize hybrids after forced inoculation at the four-leaf stage.

Figure 5 


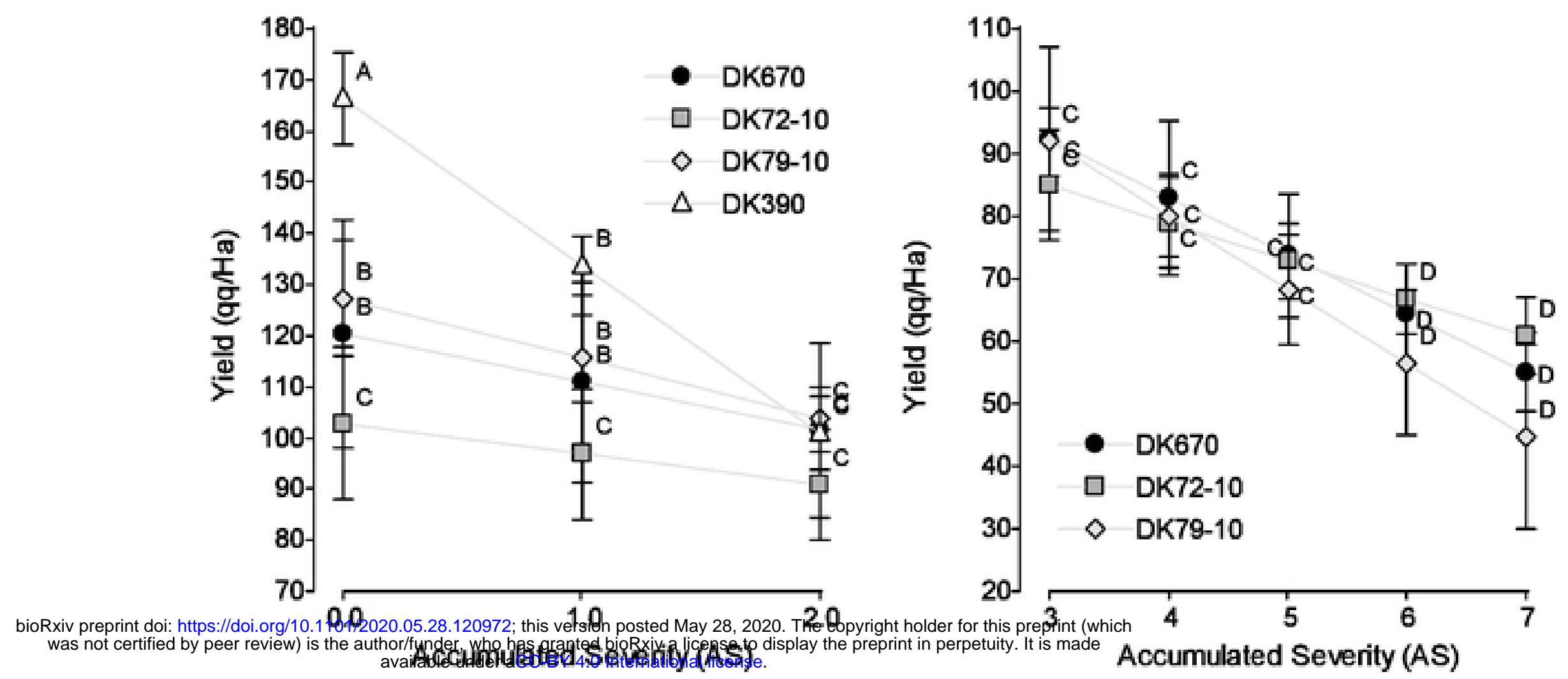

Figure 6. Relation between yield (qq/Ha) and accumulated severity (AS) of corn stunt disease symptoms. Left: Section with AS 0-2 in four maize hybrids. Right: Section with AS 3-7 excluding DKB390, because AS values were lower than 2. Values with the same letter within each panel are not significantly different according to contrasts in the mixed model test $(\alpha=0.05)$. Bars indicate standard error of the mean. 